\title{
A useful framework for teacher professional development for online and blended learning to use as guidance in times of crisis
}

\author{
Gloria Natividad Beltrán del Río ${ }^{1}$
}

Published online: 28 January 2021

(c) Association for Educational Communications and Technology 2021

Teacher professional development (TPD) started getting attention around 30 years ago. Thomas Guskey in his book "Evaluating Professional Development" (2000) stated that in the history of education, the professional development of educators had increasingly gained greater importance. Learning professionals all around the world have agreed that in order to provide meaningful learning opportunities for students, meaningful learning opportunities need to be offered also for teachers (Nel 2017; Siko and Hess 2014; Thoma et al. 2017).

Bartalo (2012) claimed that the key to providing better learning opportunities for students is by taking what we know through research and putting it into practice. One of the main goals of this Special Issue is indeed to offer the community of researchers, designers and practitioners best practices and quick solutions to address the immediate teaching and learning needs, based on several high-quality research and development papers published in ETR\&D; and to provide practical information aimed at helping educators better prepare for the future of education.

In "Improving Teacher Professional Development for Online and Blended Learning: A Systematic Meta-Aggregative Review", Philipsen et al. (2019) provide a framework for teacher professional development (PD) for online and blended learning (OBL). Philipsen et al.'s framework, which resulted from the analysis of 15 research papers published between 2004 and 2015, introduced six interrelated components: (1) Design and develop a supportive TPD program and environment for OBL; (2) Acknowledge the existing context regarding OBL; (3) Address teacher change associated with the transition to OBL; (4) Determine the overall goals and relevance of teacher PD for OBL; (5) Acknowledge teacher PD strategies associated with the transition to OBL; and (6) Disseminate knowledge, skills and attitudes about OBL and evaluate the teacher PD.

Several scholars were interested in responding to Philipsen et al.'s systematic metaaggregative review (2019). These respondents agreed that Philipsen et al.'s paper offers several valuable ideas and guidelines for reflection on how to develop TPD for OBL in times of crisis, and covered the perspectives of practice, design, international, research,

Gloria Natividad Beltrán del Río

gloria.natividad@itsaltillo.edu.mx

1 Tecnológico Nacional de México. Instituto Tecnológico de Saltillo, Blvd. Venustiano Carranza, Colonia Universidad, 25280 Saltillo, Coahuila, Mexico 
adoption and diffusion of innovation, critical pedagogy, and practice $\mathrm{K}-12$; as summarized in the following table:

\begin{tabular}{lll}
\hline Respondents & Perspective & Title \\
\hline Aytac Gogus & Adoption \& Diffusion & $\begin{array}{l}\text { Shifting to digital: Adop- } \\
\text { tion and diffusion }\end{array}$ \\
& & \\
& Research & $\begin{array}{l}\text { Shifting Digital, Shifting } \\
\text { Context: (Re)Consider- } \\
\text { ing Teacher Profes- } \\
\text { sional Development for } \\
\text { Online and Blended } \\
\text { Learning }\end{array}$ \\
& &
\end{tabular}

Florence R. Sullivan Critical Pedagogy

Javier Portillo Berasaluce International \& Arantzazu Lopez de la Serna

Serdar Abaci, Judy Rob-
ertson, Holly Linklater, \& Fiona McNeill

Tania Heap, Ruthanne Thompson \& Adam Fein

Yunjo An

Practice

K-12

Practice

\section{Design}

Philipsen et al.'s framework value and impact

To plan, develop, and implement an effective and efficient TPD for OBL contributes to teachers' adoption and diffusion

The impact of this study is that it resulted in a guiding framework that provides a potential model of inquiry to examine TPD for OBL strategies employed in a crisis context

The value of this study is in its Implicit alignment with critical methodologies development for online and blended learning: The equity imperative in the shift to digital

Response Article to "Improving Teacher Professional Development for Online and Blended Learning: A Systematic MetaAggregative Review" from an International Perspective

Supporting School Teachers' Rapid Engagement with Online Education

Designing Teacher Professional Development Programs to Support a Rapid Shift to Digital

A Response to an Article Entitled: "Improving Teacher Professional Development for Online and Blended Learning: A Systematic Meta-Aggregative Review"
The findings can be an appropriate TPD for the recovery as well as for a resilient education system

TPD became immediately relevant and highly sought after, and this framework provides useful ideas and guidance for preparing K-12 teachers for OBL

The findings offer insights into the design and development of curricula that help teachers become successful in online environments

Few existing studies examined the potential differences between generalized teacher PD and teacher PD for OBL; Philipsen et al. addressed this gap clearly applied to guide 
These seven responses to Philipsen et al.'s study provide practical information for Educational Professionals by connecting published research to the current global crisis of rapidly moving face-to-face teaching and learning to online delivery, which was the purpose of this special issue.

\section{References}

Bartalo, D. B. (2012). Closing the teaching gap: Coaching for instructional leaders. Thousand Oaks, CA: Corwin Press.

Guskey, T. R. (2000). Evaluating professional development. Thousand Oaks, CA: Corwin.

Nel, L. (2017). Students as collaborators in creating meaningful learning experiences in technologyenhanced classrooms: An engaged scholarship approach. British Journal of Educational Technology, 48, 1131-1142. https://doi.org/10.1111/bjet.12549.

Philipsen, B., Tondeur, J., ParejaRoblin, N., et al. (2019). Improving teacher professional development for online and blended learning: A systematic meta-aggregative review. Educational Technology Research \& Development, 67, 1145-1174. https://doi.org/10.1007/s11423-019-09645-8.

Siko, J. P., \& Hess, A. N. (2014). Win-win professional development: Providing meaningful professional development while meeting the needs of all stakeholders. TechTrends, 58, 99-108. https://doi. org/10.1007/s11528-014-0809-7.

Thoma, J., Johnson, D., Johnson, K., \& Stromer, E. (2017). Planning for technology integration in a professional learning community. The Reading Teacher, 71(2), 167-175. https://doi.org/10.1002/trtr.1604.

Publisher's Note Springer Nature remains neutral with regard to jurisdictional claims in published maps and institutional affiliations.

Gloria Natividad Beltrán del Río is a Professor at the Tecnológico Nacional de México, Instituto Tecnológico de Saltillo, México. She earned her M.C. in Applied Technology, Training and Development and her Ph.D. in Applied Technology and Performance Improvement from the University of North Texas. Her dissertation captured the trends in a number of research streams within the discipline of educational technology and identified the point in time when massive changes took place, and was eventually transformed into a book: An Analysis of Two Decades of Educational Technology Publications: Who, What, and Where, co-authored by Drs. J. Michael Spector and Nicholas Evangelopoulos. Dr. Natividad began serving ETR\&D Educational Technology, Research and Development journal, as an editorial assistant and later as an assistant editor for the Development Section. She serves as a Co-Editor for the online Major Reference Work (MRW) co-sponsored by AECT and Springer entitled Learning, Design, and Technology: An International Compendium of Theory, Research, Practice and Policy; for the Literature Reviews and Systematic Reviews of Research Section. 